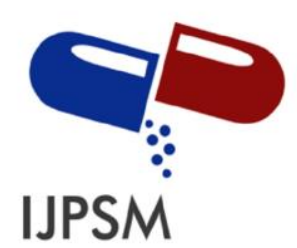

Rida Rosa et al, International Journal of Pharmaceutical Sciences and Medicine (IJPSM),

Vol.6 Issue. 7, July- 2021, pg. 40-49

\title{
Phytochemical and Antihypertensive Tests of Celery (Apium graveolens L.) and Garlic (Allium sativum L.) Formula
}

\author{
Rida Rosa; Harrizul Rivai* \\ Faculty of Pharmacy, Andalas University, Limau Manih Campus, Padang 25163, Indonesia, \\ harrizul@yahoo.co.id; harrizul@ phar.unand.ac.id; ridha.rossa@gmail.com
}

DOI: 10.47760/ijpsm.2021.v06i07.004

\begin{abstract}
Hypertension is also the leading cause of death worldwide. Treatment and control of hypertension help prevent cardiovascular death. Traditionally celery and garlic have been used as ingredients to lower high blood pressure by the people of South Sulawesi. Phytochemical testing was carried out to provide information about compounds' content in the formula of celery and garlic. Furthermore, the determination of the levels of alkaloids and saponins was carried out gravimetrically, the decision of the stories of phenols with a UV-Visible spectrophotometer, and the conclusion of the levels tannins with a UV spectrophotometer. Pharmacological testing using 25 white male rats were treated with doses of celery and garlic formula given to rats, namely $185 \mathrm{mg} / 200 \mathrm{~g} \mathrm{BW}, 370 \mathrm{mg} / 200 \mathrm{~g} \mathrm{BW}, 740 \mathrm{mg} / 200 \mathrm{~g} \mathrm{BW}$ orally as test material. In the negative control, the rats were only given distilled water alone, and in the positive control, it was induced using $8 \% \mathrm{NaCl}$ and $0.05 \%$ prednisone orally. The test solution was given for 21 days. The results of the phytochemical test showed that the celery and garlic ingredients contained positive alkaloids, saponins, phenols, tannins with levels of $1.8917 \%$ alkaloids, $0.5885 \%$ saponins, $1.6138 \%$ phenols, and 1,3485 \% tannins. Pharmacological test results showed systolic blood pressure and diastolic blood pressure decreased significantly $(\mathrm{p}<0.05)$.
\end{abstract}

Keywords: Phytochemical, Antihypertensive, Apium graveolens L, Allium sativum L., formula

\section{Introduction}

Hypertension is the leading cause of death worldwide. Treatment and control of hypertension help prevent cardiovascular death [1]. Garlic (Allium sativum L.) has traditionally been used for heart medicine. Garlic extract is effective as adjunctive therapy for the standard treatment of hypertension in a patient population with systolic blood pressure greater than $140 \mathrm{mmHg}$ [2].

Celery leaf extract can be considered as an antihypertensive agent in the chronic treatment of elevated systolic blood pressure [3]. After researching the effect of celery juice on reducing blood pressure in Bakalan Village, Kalinyamatan District, Jepara in 2019, it can be concluded that there is a significant effect. Celery juice has a strong tolerance for systolic blood pressure and diastolic blood pressure [4].

Based on this background, there has been no research examining the content and levels of compounds in garlic and celery ingredients and their effect on reducing high blood pressure. Therefore, researchers are interested in reviewing the components of garlic and celery as used by the people of South Sulawesi. The people of South Sulawesi Province use a concoction of garlic and celery to help lower their blood pressure. The concoction is made by finely chopped garlic and celery, mixed, kneaded, then added with water and filtered, drunk every morning [5]. 


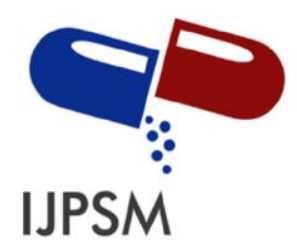

Rida Rosa et al, International Journal of Pharmaceutical Sciences and Medicine (IJPSM), Vol.6 Issue. 7, July- 2021, pg. 40-49

ISSN: 2519-9889

Impact Factor: 3.426

\section{Research methods}

\subsection{Research tools, materials, and Experimental Animals}

The tools used in this study were UV-Vis spectrophotometer (Shimadzu), an instrument blood pressure gauge NIBP (Non-invasive blood pressure) brand CODA (Kent Scientific).

The materials used in this study were celery, garlic, ethanol (Merck), distilled water (Bratachem), concentrated sulfuric acid (Merck), iron (III) chloride (Merck), hydrochloric acid (Merck), acetic acid (Merck), potassium hydroxide (Merck), chloroform (Merck), boric acid (Merck), oxalic acid (Merck), ethyl acetate (Bratachem), acetone (Merck), methanol (Bratachem), Sodium Chloride (Bratacho®), Hi- Pro-Vite 511 (PT. Charoen Indonesia), ammonia (Bratachem), anhydrous sodium sulfate (Merck), ethyl acetate (Bratachem), zinc powder (Merck), magnesium powder (Merck), sodium hydroxide (Merck), gallic acid (Merck), aluminum chloride (Bratachem), sodium acetate (Merck), benzene (Bratachem), butanol (Bratachem), acetic acid (Bratachem).

The experimental animals used were white male Wistar rats aged 2-3 months with a bodyweight of 200-300 grams; as many as 25 rats were divided into five groups with five rats in each group.

\subsection{Making celery and garlic formula}

Garlic 1 (one) clove weighing one clove $1.4336 \mathrm{~g}$ and celery ( \pm 16 sticks) weighing one stick $1.20 \mathrm{~g}$ finely chopped, mixed and added with $100 \mathrm{~mL}$ of water then blended and filtered [5].

\subsection{Phytochemical analysis}

\section{Qualitative analysis}

a. Identification of alkaloids [6].

Pipette $1 \mathrm{~mL}$ of the concoction, add $1 \mathrm{~mL}$ of $2 \mathrm{~N}$ and $9 \mathrm{~mL}$ hydrochloric acid, heat on a water bath for 2 minutes, cool, and filter. Transfer 3 drops of the filtrate to the watch glass, add two drops of Bouchardat LP. If in both experiments no precipitate occurs, then the powder does not contain alkaloids.

Suppose with Mayer LP a white or yellow precipitate is formed, which dissolves in methanol P, and with Bouchardat LP, a brown to black deposition is created. In that case, there is a possibility that alkaloids are present.

b. Identification of Glycosides [6].

Experimental solution

Pipette $6 \mathrm{~mL}$ of the mixture with $30 \mathrm{~mL}$ of a combination of 7 parts by volume of ethanol (95\%) $\mathrm{P}$ and three parts by volume of water in a backflow more excellent for 10 minutes, filter. To $20 \mathrm{~mL}$ of the filtrate, add $25 \mathrm{~mL}$ of water and $25 \mathrm{~mL}$ of $0.4 \mathrm{M}$ lead (II) acetate, shake, let stand for 5 minutes, filter. Extract the filtrate three times, each time with 20 parts by volume of isopropanol P, filter, and evaporate at a temperature not exceeding $50^{\circ}$. Dissolve the remainder with $2 \mathrm{~mL}$ of methanol $\mathrm{P}$.

Experiments on glycosides

Evaporate $0.1 \mathrm{~mL}$ of the practical solution on a water bath, dissolve the remainder in $5 \mathrm{~mL}$ of anhydrous acetic acid P. Add ten drops of sulfuric acid P; a blue or green color occurs, indicating the presence of glycosides (Liebermann-Burchard reaction).

Put $0.1 \mathrm{~mL}$ of the practical solution in a test tube, vaporize it on a water bath. To the remainder, add 2 $\mathrm{mL}$ of sulfuric acid P; A purple ring is formed at the liquid boundary, indicating the presence of sugar bonds (Molisch reaction).

c. Identification of saponins [6].

Put $1 \mathrm{ml}$ of the tested ingredients into a test tube, add $10 \mathrm{ml}$ of hot water. Cool and then shake vigorously for 10 seconds (if the substance under examination is a liquid preparation, dilute $1 \mathrm{ml}$ of the preparation under examination with $10 \mathrm{ml}$ and shake vigorously for 10 minutes); a steady froth is formed for not less than 10 minutes, $1 \mathrm{~cm}$ to $10 \mathrm{~cm}$ high. On the addition of 1 drop of $2 \mathrm{~N}$ hydrochloric acid, the foam does not disappear. 


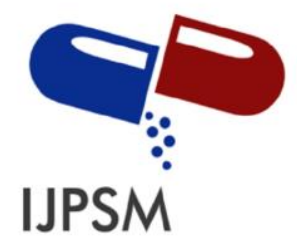

Rida Rosa et al, International Journal of Pharmaceutical Sciences and Medicine (IJPSM), Vol.6 Issue. 7, July- 2021, pg. 40-49

ISSN: 2519-9889

Impact Factor: 3.426

d. Identification of Flavonoids [6].

Practical solution:

Extract $10 \mathrm{ml}$ of the mixture with $10 \mathrm{ml}$ of methanol P, using a backflow cooler for 10 minutes. Filter the heat through small folded filter paper, dilute the filtrate with $10 \mathrm{ml}$ of water. After cooling, add 5 $\mathrm{mL}$ of petroleum ether $\mathrm{P}$, shake carefully, let stand. Take a layer of methanol, vaporize it at $40^{\circ}$ under pressure. The remainder is dissolved in $5 \mathrm{ml}$ of ethyl acetate $\mathrm{P}$, filtered.

Experiment

Evaporate to dryness $1 \mathrm{~mL}$ of the experimental solution. The remainder is dissolved in $1 \mathrm{~mL}$ to $2 \mathrm{~mL}$ of ethanol (95\%) P; Add $0.5 \mathrm{~g}$ of zinc $\mathrm{P}$ powder and $2 \mathrm{~mL}$ of $2 \mathrm{~N}$ hydrochloric acids, let stand for 1 minute. Add $10 \mathrm{~mL}$ of concentrated hydrochloric acid if an intense red color occurs within 2 to 5 minutes, indicating the presence of flavonoids (glycoside-3-flavonol).

Evaporate to dry $1 \mathrm{~mL}$ of the experimental solution. The remainder is dissolved in $1 \mathrm{~mL}$ of ethanol (95\%) P; Add $0.1 \mathrm{~g}$ of magnesium powder and $10 \mathrm{~mL}$ of concentrated hydrochloric acid. If a redorange to purple color occurs, it indicates the presence of flavonoids. If a yellow-orange color appears, it means the company of flavones, chalcones, and aurons.

e. Identification of amino acids

$0.1 \%$ Ninhydrin-acetone solution

The reagent solution was made fresh and carried out with slight heating. Add a few drops of $0.1 \%$ ninhydrin-acetone solution to a few drops of the extract. Generally, amino acids give a purple to grayblue color, except for proline which gives a yellow color [7].

f. Identify carbohydrates

Fehling's Solution A and Fehling's Solution B

Identification is carried out by adding equal amounts of Fehling A and Fehling B solutions into the test solution. Then reduction will occur (sometimes heating is required), producing a brick red copper oxide residue [7].

Molisch reaction

All carbohydrates give a purple color when reacted with $\alpha$-naphthol and nitric acid. The formation of a purple ring indicates the presence of carbohydrates [7].

g. Identification of Fatty Acids

$25 \%$ Sulfuric Acid Solution

Add a few drops of $25 \%$ sulfuric acid to a few drops of the extract, then heat it until a light brown color is formed [7].

h. Identification of Phenol

Iron (III) chloride solution

Add some iron (III) chloride salt solution to a few drops of the extract if it gives a green to a blue-

black color indicating the presence of phenol [7].

Folin-Ciocalteu

Add a few drops of Folin-Ciocalteu solution to a few drops of the extract. If there is a color change, it indicates the presence of phenol [7].

i. Identification of Essential Oils

Potassium Permanganate Solution

Add a few drops of potassium permanganate solution to a few drops of the extract. The color will turn pale or disappear, indicating the presence of essential oils [7].

Acetic Anhydride Solution

Add a few drops of acetic anhydride to a few drops of the extract, then add $1 \mathrm{~mL}$ of concentrated sulfuric acid so that a blue, green color appears, indicating the presence of essential oils [7].

Quantitative analysis of total levels of chemical compounds

a. Determination of Total Phenolic Compound Concentration with Phenol Folin-Ciocalteu Method Preparation of test solution. 


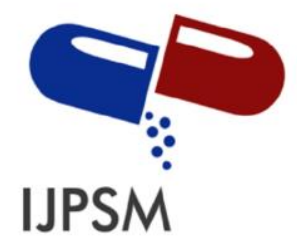

Rida Rosa et al, International Journal of Pharmaceutical Sciences and Medicine (IJPSM), Vol.6 Issue. 7, July- 2021, pg. 40-49

ISSN: 2519-9889

Impact Factor: 3.426

Pipette $2 \mathrm{~mL}$ of liquid extract, dilute with methanol to the mark in a $100 \mathrm{~mL}$ volumetric flask. Then the $2 \mathrm{~mL}$ pipette was put into a $10 \mathrm{~mL}$ volumetric flask and diluted with methanol to the mark.

Making comparison solution

Weigh approximately $10 \mathrm{mg}$ of the gallic acid comparator (immediate solution), dissolve with methanol to the mark in a $25 \mathrm{~mL}$ volumetric flask, dilute quantitatively. If necessary, gradually with methanol at concentrations of $30,40,50,60$, and $70 \mu \mathrm{g} / \mathrm{mL}$ gallic acid mother liquor by pipetting $0.75,1,1.25,1.5,1.75 \mathrm{~mL}$ and diluted with a mixture of methanol and distilled water (1:1) in a $10 \mathrm{~mL}$ volumetric flask to the mark.

Measurement

Pipette $1 \mathrm{~mL}$ of the test solution and a comparison solution in a test tube, add $5 \mathrm{~mL}$ of aqueous FolinCiocalteu phenol LP (7.5\% water). Let stand for 8 minutes, add $4 \mathrm{~mL}$ of $1 \%$ sodium hydroxide, let stand for 1 hour. Maximum wavelength absorption is carried out at a comparison concentration of 50 ppm with methanol as a blank at a wavelength of $761 \mathrm{~nm}$, creating a calibration curve and calculating the total phenol content [8].

b. Determination of Total Tannin Content

Comparison solution

Dry the catechin comparator in an oven at $105^{\circ} \mathrm{C}$ until the weight remains constant. Accurately weigh approximately $10 \mathrm{mg}$, put into a $10 \mathrm{~mL}$ measuring flask, dissolve in ethyl acetate, sonicate for 5 minutes. Pipette $2 \mathrm{~mL}$ of the solution, put into a $100 \mathrm{~mL}$ glass-stoppered Erlenmeyer flask, add $50 \mathrm{~mL}$ of ethyl acetate, sonicate again for 5 minutes.

Test solution

Take $20 \mathrm{~mL}$ of the liquid extract into a $50 \mathrm{~mL}$ measuring flask, dissolve in ethyl acetate, sonicate for 5 minutes. Pipette $2 \mathrm{~mL}$ of the solution, put into a $100 \mathrm{~mL}$ glass-stoppered Erlenmeyer flask, add $50 \mathrm{~mL}$ of ethyl acetate, sonicate again for 5 minutes.

Measurement

Measure the absorption of the reference solution, test solution, and blank solution spectrophotometrically at a wavelength of $280 \mathrm{~nm}$. Use ethyl acetate as a blank. Calculate the percentage of catechins in the extract at a wavelength of $280 \mathrm{~nm}$ [9].

c. Determination of Total Alkaloid Level

Enter the mixture of approximately $10 \mathrm{ml}$ into the Erlenmeyer, then add $100 \mathrm{ml}$ of methanol P and 10 $\mathrm{ml}$ of ammonia $\mathrm{P}$, heat over a water bath for 30 minutes, filter. Repeat the filtration two times using the same type and amount of solvent. Add $50 \mathrm{ml}$ of $1 \mathrm{~N}$ LP hydrochloric acid and collect the filtrate, evaporate to a volume of approximately $25 \mathrm{ml}$, filter into a separating funnel. The filtrate was alkalized with ammonia $\mathrm{P}$ to $\mathrm{pH} \pm 10$ using a $\mathrm{pH}$ indicator, extracted three times with $25 \mathrm{ml}$ of chloroform P. The chloroform phase was collected and evaporated at $50^{\circ} \mathrm{C}$, then dried at $100^{\circ} \mathrm{C}$ to constant weight. Calculate the residual drying as total alkaloids [10].

d. Determination of Total Saponin Levels

Take $50 \mathrm{~mL}$ of liquid extract, extract using $100 \mathrm{~mL}$ of $20 \%$ ethanol in water, heat on a water bath for 4 hours at $55{ }^{\circ} \mathrm{C}$ while occasionally stirring filter. The remainder is extracted again with $200 \mathrm{~mL}$ of $20 \%$ ethanol in water, filtered. Combine the two extracts and then evaporate to $40 \mathrm{~mL}$ on a water bath at $90{ }^{\circ} \mathrm{C}$. Then the extract was put into a $250 \mathrm{~mL}$ separatory funnel plus $20 \mathrm{~mL}$ of diethyl ether, shaken vigorously. The aqueous layer is deposited, the remaining ether layer is added to $20 \mathrm{~mL}$ of diethyl ether, shaken. Repeat until the water layer is transparent. Combine the water layers and then add $60 \mathrm{~mL}$ of n-butanol, wash with $10 \mathrm{~mL}$ of $5 \%$ sodium chloride. Take a layer of $\mathrm{n}$-butanol and then evaporate to dryness at a temperature of $60^{\circ} \mathrm{C}$. Calculate the residual drying as total saponins [11]. 


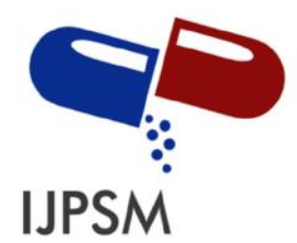

Rida Rosa et al, International Journal of Pharmaceutical Sciences and Medicine (IJPSM), Vol.6 Issue. 7, July- 2021, pg. 40-49

ISSN: 2519-9889

Impact Factor: 3.426

\subsection{Pharmacological test}

a. Preparation of experimental animals

The experimental animals were acclimatized for seven days to get the animals used to the experimental conditions and were given adequate food and drink. Then the animals were weighed, and their behavior was observed. During rearing, the weight of the animals was considered, and their behavior was observed. Animals are declared suitable for use if their behavior is normal and they do not experience more than $10 \%$ [12]. After the acclimatization period, the rats' blood pressure was measured to determine the initial blood pressure. Then the animals were induced with $8 \% \mathrm{NaCl}$ and $0.05 \%$ prednisone to obtain hypertensive rats.

b. Dose planning and rat grouping

After obtaining hypertensive animals, then the celery and garlic concoction was given to rats at a dose of $185 \mathrm{mg} / 200 \mathrm{~g} \mathrm{BW}$ (dose 1), $370 \mathrm{mg} / 200 \mathrm{~g} \mathrm{BW}$ (dose 2), $740 \mathrm{mg} / 200 \mathrm{~g} \mathrm{BW}$ (dose 3) orally. As a test material, dose 1 was given $0.9 \mathrm{~mL}$; dose 2 was given as much as $1.8 \mathrm{~mL}$; dose 3 was given as much as $3.6 \mathrm{~mL}$. In the negative control, the rats were only given distilled water, and in the positive control, hypertension was induced using $8 \% \mathrm{NaCl}$ and $0.05 \%$ prednisone orally. The suspension of the test was carried out for 21 days.

c. Measurement of high blood pressure on test animals

Before measuring blood pressure, CODA (Kent Scientific) Non-invasive blood pressure is connected to a computer. Animals are put in a sleeve tube. After that, the rat tail was clamped with a blood pressure sensor. After the conditions of the experimental animals began to be conducive, blood pressure measurements were carried out with the CODA device. Blood pressure (systolic and diastolic blood pressure) is read on a computer. The first blood pressure measurement was carried out after acclimatization before induction of $8 \% \mathrm{NaCl}$ at a dose of $160 \mathrm{mg}$ and prednisone $0.05 \%$ at a dose of 1 $\mathrm{mg}$. Furthermore, blood pressure was measured after the administration of the test preparation/herb [13].

\subsection{Data analysis}

The data were statistically tested using the two-way ANOVA test. If $\mathrm{P}<0.05$, then continued with Duncan's test to determine the difference in the mean decrease in blood pressure between the treatment groups.

\section{Results and Discussion}

Examining the qualitative analysis of the ingredients of celery and garlic showed positive results on alkaloid compounds, saponins, phenols, tannins (Table 1 and Figure 1).

Table 1: Phytochemical test results of celery and garlic formula

\begin{tabular}{|l|l|c|}
\hline \multicolumn{1}{|c|}{ Compound } & \multicolumn{1}{|c|}{ Test } & Phytochemical Results \\
\hline \multirow{2}{*}{ Alkaloids } & $\mathrm{HCl} 2 \mathrm{~N}+$ Bouchardat LP & $\begin{array}{c}+ \\
\text { (brown precipitate) }\end{array}$ \\
\cline { 2 - 3 } & Mayer LP & $\begin{array}{c}+ \\
\text { (white residue) }\end{array}$ \\
\hline Saponins & Foam Reaction & $\begin{array}{c}+ \\
\text { (foam height } 1.4 \mathrm{~cm})\end{array}$ \\
\hline \multirow{2}{*}{ Phenol } & $\mathrm{FeCl}_{3}$ & $\begin{array}{c}+ \\
\text { (brown green) }\end{array}$ \\
\cline { 2 - 3 } & $\mathrm{Folin}^{2}$ Ciocalteu & $\begin{array}{c}+ \\
\text { (blue) }\end{array}$ \\
\hline Tannins & $\mathrm{FeCl}_{3}$ & $\begin{array}{c}+ \\
\text { (brown green) }\end{array}$ \\
\hline
\end{tabular}




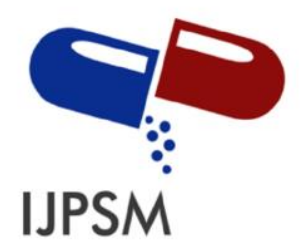

Rida Rosa et al, International Journal of Pharmaceutical Sciences and Medicine (IJPSM), Vol.6 Issue. 7, July- 2021, pg. 40-49

ISSN: 2519-9889

Impact Factor: 3.426
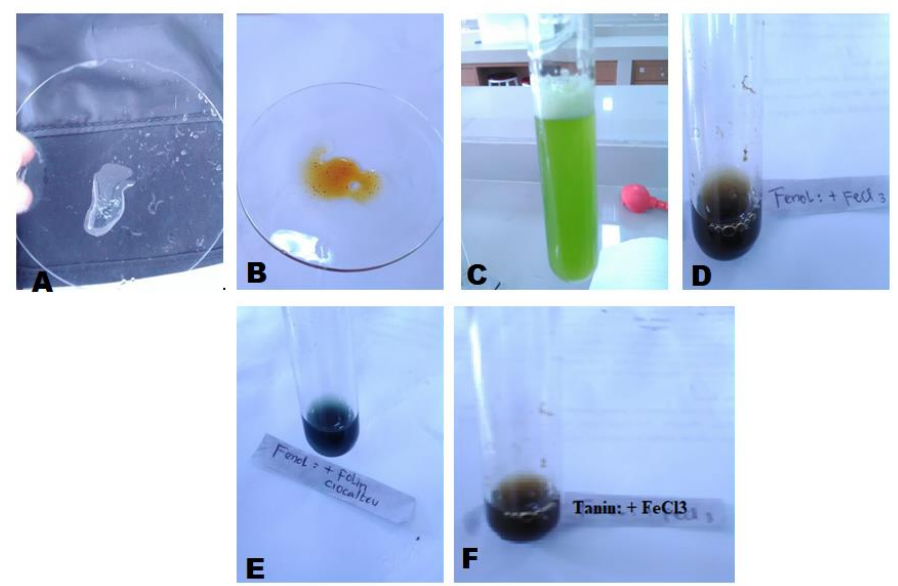

Figure 1: Phytochemical test results of celery and garlic formula. (A-B) Alkaloids; (C) Saponins; (D-E) Phenol; (F) Tannins

Based on the results of the phytochemical test in Table 1 and Figure 1, there are two ways to test for alkaloids, namely by using Mayer LP reagent and Bouchardat LP reagent. The reaction using Mayer LP reagent showed a white residue, and with Bouchardat LP, it produced a brown residue. It indicates that the herb contains alkaloid compounds. In the determination of the alkaloid content obtained an average alkaloid content of $1.8917 \%$.

The results of the saponin test using $1 \mathrm{~mL}$ of the herb put into a test tube, add $10 \mathrm{~mL}$ of hot water which is shaken vigorously for 10 seconds, and the results obtained are the occurrence of foam as high as $1.4 \mathrm{~cm}$ indicates a positive impact. In the determination of saponin levels, the average saponin content is $0.5885 \%$.

The results of the phenol test by adding a solution of iron (III) chloride, the results obtained were a color change to brownish green, on the addition of Folin-Ciocalteu, the results obtained were a color change to blue, this showed a positive impact. In determining the phenol content, the average phenol content was $1.6138 \%$.

The results of the tannin test with iron (III) chloride reagent showed positive results; namely, the solution turned brownish-green. In the determination of the tannin content, the average tannin content was $1,3485 \%$.

In Table 2, it can be seen that the mean initial systolic blood pressure before induction in each dose group was expected. At the time after being induced, the mean systolic blood pressure was above normal/hypertension. After giving the formula on the 7th and 14th days, the average systolic blood pressure has started to look lower but not maximal. On the 21 st day of the concoction, the moderate systolic blood pressure had begun to return to normal, meaning that the formula given had the effect of lowering high blood pressure.

Table 2: Systolic Blood Pressure ( $\mathrm{mmHg}$ )

\begin{tabular}{|c|c|r|r|r|r|r|}
\hline \multirow{3}{*}{ Group } & \multirow{2}{*}{ No. Rat } & \multicolumn{5}{|c|}{ Treatment } \\
\cline { 3 - 7 } & & BP before & \multirow{2}{*}{$\begin{array}{c}\text { BP after } \\
\text { induction }\end{array}$} & \multicolumn{2}{|c|}{ BP after administration of test formula } \\
\cline { 3 - 7 } & & 122.60 & 119.00 & 116.00 & 115.00 & 112.20 \\
\hline \multirow{3}{*}{$\begin{array}{c}\text { Negative } \\
\text { control }\end{array}$} & 2 & 100.20 & 111.14 & 109.14 & 106.00 & 94.25 \\
\cline { 2 - 7 } & 3 & 108.29 & 106.25 & 117.20 & 106.25 & 105.67 \\
\cline { 2 - 7 } & 4 & 119.00 & 117.25 & 110.43 & 106.50 & 102.00 \\
\hline
\end{tabular}




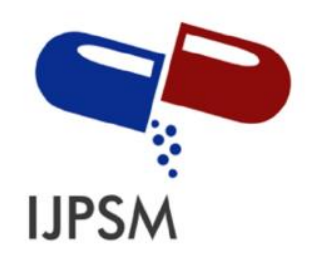

Rida Rosa et al, International Journal of Pharmaceutical Sciences and Medicine (IJPSM), Vol.6 Issue. 7, July- 2021, pg. 40-49

ISSN: 2519-9889

Impact Factor: 3.426



In Table 3, it can be seen that the mean initial diastolic blood pressure before induction in each dose group was expected. At the time after being induced, the mean systolic blood pressure was above normal/hypertension. After giving the formula on the 7th and 14th days, the average diastolic blood pressure started to look lower but not maximal. On the 21 st day of formula administration, the moderate diastolic blood pressure had begun to return to normal, meaning that the formula given had the effect of lowering high blood pressure. 


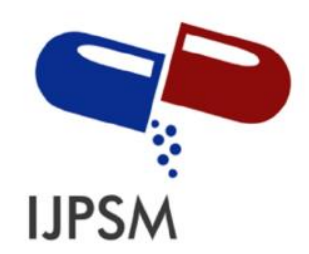

Rida Rosa et al, International Journal of Pharmaceutical Sciences and Medicine (IJPSM), Vol.6 Issue. 7, July- 2021, pg. 40-49

ISSN: 2519-9889

Impact Factor: 3.426

Table 3: Diastolic Blood Pressure (mmHg)

\begin{tabular}{|c|c|c|c|c|c|c|}
\hline \multirow{3}{*}{ Group } & \multirow{3}{*}{ No. Rat } & \multicolumn{5}{|c|}{ Treatment } \\
\hline & & \multirow{2}{*}{$\begin{array}{l}\text { BP before } \\
\text { induction }\end{array}$} & \multirow{2}{*}{$\begin{array}{l}\text { BP after } \\
\text { induction }\end{array}$} & \multicolumn{3}{|c|}{ BP after administration of test formula } \\
\hline & & & & Day 7 & Day 14 & Day 21 \\
\hline \multirow{6}{*}{$\begin{array}{l}\text { Negative } \\
\text { control }\end{array}$} & 1 & 97.14 & 102.40 & 94.67 & 99.00 & 93.33 \\
\hline & 2 & 70.86 & 87.40 & $\overline{75.00}$ & 81.67 & 62.25 \\
\hline & 3 & 77.80 & 74.20 & 90.40 & 74.20 & 78.67 \\
\hline & 4 & 90.00 & 84.00 & 88.00 & 76.00 & $\overline{75.00}$ \\
\hline & 5 & 87.43 & 104.00 & 89.75 & 97.67 & 86.00 \\
\hline & average & 84.65 & 90.40 & 87.56 & 85.71 & 79.05 \\
\hline \multirow{6}{*}{$\begin{array}{l}\text { Positive } \\
\text { control }\end{array}$} & 1 & 92.83 & 98.00 & 111.33 & 115.80 & 99.20 \\
\hline & 2 & 91.71 & 90.60 & 91.71 & 100.33 & 101.63 \\
\hline & 3 & 60.57 & 115.00 & 101.75 & 103.17 & 110.50 \\
\hline & 4 & 77.14 & 114.40 & 117.33 & 121.00 & 134.00 \\
\hline & 5 & 80.33 & 129.00 & 125.20 & 122.60 & 111.40 \\
\hline & average & 80.52 & 109.40 & 109.46 & 112.58 & 111.35 \\
\hline \multirow{6}{*}{ dose 1} & 1 & & & & & \\
\hline & 2 & 89.17 & 103.00 & 101.75 & 83.80 & 80.80 \\
\hline & 3 & 82.29 & 123.00 & 93.33 & 92.83 & 81.67 \\
\hline & 4 & 81.43 & 125.60 & 100.57 & 99.00 & 84.67 \\
\hline & 5 & 91.63 & 111.29 & 102.80 & 93.75 & 76.80 \\
\hline & average & 86.13 & 115.72 & 99.61 & 92.35 & 80.99 \\
\hline \multirow{6}{*}{ dose 2} & 1 & 70.20 & 119.33 & 101.63 & 103.50 & 72.25 \\
\hline & 2 & 82.86 & 103.60 & 99.50 & 99.88 & 88.83 \\
\hline & 3 & 70.40 & 110.75 & 102.33 & 96.50 & 103.60 \\
\hline & 4 & 90.00 & 134.00 & 103.17 & 96.83 & 81.29 \\
\hline & 5 & 107.00 & 116.33 & 102.67 & 95.29 & 97.25 \\
\hline & average & 84.09 & 116.80 & 101.86 & 98.40 & 88.64 \\
\hline \multirow{6}{*}{ dose 3} & 1 & 101.00 & 114.78 & 105.00 & 97.88 & 98.80 \\
\hline & 2 & 79.83 & 129.25 & 91.75 & 110.33 & 70.67 \\
\hline & 3 & 91.80 & 125.67 & 112.00 & 91.20 & 70.86 \\
\hline & 4 & 100.40 & 130.67 & 102.80 & 97.17 & 89.80 \\
\hline & 5 & 104.00 & 102.67 & 101.25 & 105.50 & 78.67 \\
\hline & average & 95.41 & 120.61 & 102.56 & 100.42 & 81.76 \\
\hline
\end{tabular}

In the pharmacological test, the data obtained were processed using SPSS. The systolic blood pressure data showed an interaction between the dose group and treatment time (sig. $<0.05$ ), as well as the dose and treatment time group had a significant effect on systolic blood pressure (sig. $<0.05$ ). 


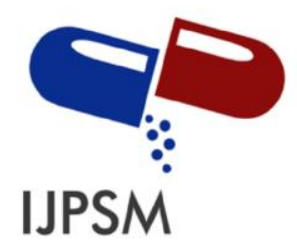

Rida Rosa et al, International Journal of Pharmaceutical Sciences and Medicine (IJPSM), Vol.6 Issue. 7, July- 2021, pg. 40-49

ISSN: 2519-9889

Impact Factor: 3.426

Diastolic blood pressure data also showed an interaction effect between the dose and treatment time group on diastolic blood pressure (Sig. $0.001<0.05$ ). In contrast, the dose and treatment time group significantly affected diastolic blood pressure (Sig. $0.000<0.05$ ).

The description of the research results above shows that the ingredients of celery (Apium graveolens L.) and garlic (Allium sativum L.) contain alkaloids, saponins, phenols, and tannins. The saponins have the potential as diuretics by reducing plasma volume by removing water and electrolytes, especially sodium so that cardiac output decreases [14]. Tannins are natural polyphenols, have an inhibitory action on the angiotensin-converting enzyme (ACE). Several studies have shown that phenolic compounds isolated from various plants and some pure flavonoids can inhibit ACE activity and lower blood pressure [15].

\section{Conclusion}

The results of the phytochemical test showed that the celery and garlic ingredients contained alkaloids, saponins, phenols, tannins with levels of $1.8917 \%$ alkaloids, $0.5885 \%$ saponins, 1,6138\% phenols, and $1,3485 \%$ tannins. Pharmacological test results showed systolic blood pressure and diastolic blood pressure decreased significantly $(\mathrm{p}<0.05)$. Therefore, the ingredients of celery and garlic can be used as an alternative treatment to lower high blood pressure.

\section{References}

[1]. Burnier M, Egan BM. Adherence in hypertension: a review of prevalence, risk factors, impact, and management. Circulation research. 2019 Mar 29;124(7):1124-40.

[2]. Chan WJ, McLachlan AJ, Luca EJ, Harnett JE. Garlic (Allium sativum L.) in the management of hypertension and dyslipidemia-A systematic review. Journal of Herbal Medicine. 2020 Feb 1;19:100292.

[3]. Dianat M, Veisi A, Ahangarpour A, Moghaddam HF. Hydro-alcoholic celery (Apium graveolens) leaf extract on cardiovascular parameters and lipid profile in an animal model of hypertension induced by fructose. Avicenna journal of phytomedicine. 2015 May;5(3):203.

[4]. Azizah NC, Astuti D, Fanani Z, Karyati S, Kurnia W. The Influence of Celery Juice Against Blood Pressure Reduction in Hypertension. In Journal of Physics: Conference Series 2020 Mar 1 (Vol. 1477, No. 6, p. 062009). IOP Publishing.

[5]. BPOM RI. Formularium Ramuan Obat Tradisional Indonesia. Volume 1. Badan Pengawas Obat Dan Makanan Republik Indonesia. Jakarta. 2011.

[6]. Depkes RI. Materia Medika Indonesia, Jilid IV. Direktorat Jenderal Pengawasan Obat Dan Makanan. Jakarta. 1995.

[7]. Hanani, E. Analisis fitokimia. Buku Kedokteran EGC. Jakarta.2015.

[8]. Kementerian Kesehatan Repubik Indonesia. Farmakope Herbal Indonesia. Edisi II. Kementerian Kesehatan Republik Indonesia. Jakarta. 2017.

[9]. Kementerian Kesehatan Republik Indonesia. Farmakope Herbal Indonesia. (Suplemen I). Kementerian Kesehatan Republik Indonesia. Jakarta. 2010.

[10]. Depkes RI. Farmakope Herbal Indonesia Edisi 1. Departemen Kesehatan Republik Indonesia. Jakarta. 2008.

[11]. Edeoga HO, Okwu DE, Mbaebie BO. Phytochemical constituents of some Nigerian medicinal plants. African journal of biotechnology. 2005 Aug 19;4(7):685-8.

[12]. Vogel HG, editor. Drug discovery and evaluation: pharmacological assays. Springer Science \& Business Media; 2002 Jun 13.

[13]. Harmely F, Nasrul E, Umar S, Zaini E, Aldi Y. Pengaruh Dispersi Padat Irbesartan-Poloxamer 188 Terhadap Tekanan Darah dan Kadar Nitric Oxide (NO) Pada Tikus Puth Jantan Hipertensi. Jurnal Sains Farmasi \& Klinis. 2018 Oct 11;5(2):88-93.

[14]. de Souza AM, da Silva Lara L, Previato JO, Lopes AG, Caruso-Neves C, da Silva BP, Parente JP. Modulation of sodium pumps by steroidal saponins. Zeitschrift für Naturforschung C. 2004 Jun 1;59(5-6):432-6.

[15]. Al Shukor N, Van Camp J, Gonzales GB, Staljanssens D, Struijs K, Zotti MJ, Raes K, Smagghe G. Angiotensinconverting enzyme inhibitory effects by plant phenolic compounds: A study of structure-activity relationships. Journal of agricultural and food chemistry. 2013 Dec 4;61(48):11832-9. 


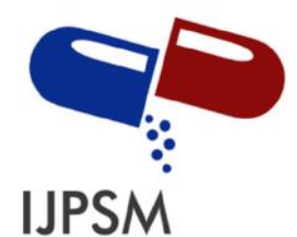

Rida Rosa et al, International Journal of Pharmaceutical Sciences and Medicine (IJPSM), Vol.6 Issue. 7, July- 2021, pg. 40-49

ISSN: 2519-9889

Impact Factor: 3.426

\section{A Brief Author Biography}

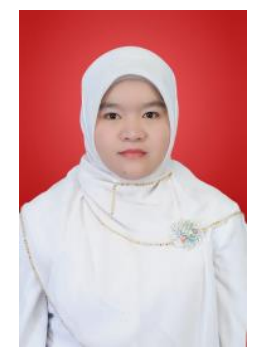

Apt. Rida Rosa, S. Farm was born in Padang, West Sumatra, on April 22, 1986. Her father is Ridwan Ali, and her mother is Roslaini. The Author holds a Bachelor's degree in Pharmacy from the Indonesian College of Pharmacy, Yayasan Perintis Padang (2010), and a Pharmacist from the Faculty of Mathematics and Natural Sciences, Andalas University, Padang (2011). Currently, the Author is a graduate student at the Faculty of Pharmacy, Andalas University, Padang. The Author also serves as Managing Pharmacist at Raissa Pharmacy.

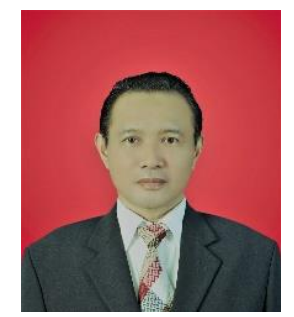

Prof. DR. Harrizul Rivai, M.S. was born in Payakumbuh, West Sumatra, on 4 September 1953. His father is Rivai Said, and his mother is Saridahanum Syofyan. The Author obtained a Bachelor of Pharmacy from the Department of Pharmacy, Faculty of Mathematics and Natural Sciences, Padjajaran University, Bandung (1976), a Master of Science degree from the Bandung Institute of Technology (1984), and a Doctorate from the Department of Chemistry, Faculty of Mathematics and Natural Sciences, Andalas University, Padang (2011). Now the Author is a Professor and Researcher at the Faculty of Pharmacy, Andalas University, Padang. The Author also serves as Deputy Chair of Academic Affairs at the YPTIK Padang College of Pharmacy (STIFARM). The Author wrote the book "Principles of Chemical Examination" (Publisher UI-Press, 1995), translated the book "Pharmaceutical Statistics" (EGC Medical Book Publishers, 2010), and wrote "Chapter 4" in the book "Recent Research Advances in Biology Vol. 4" (Book Publisher International, India, and United Kingdom, 2020), and wrote the book "Chinese Petai (Leucaena leucocephala): Traditional Uses, Phytochemicals, and Pharmacological Activities" (Deepublish, Yogyakarta, 2021). He wrote "Chapter 9" in the book "Recent Research Advances in Biology Vol. 7" and "Chapters 5, 6, 7, and 8" in the book "Technological Innovation in Pharmaceutical Research Vol. 3 (Book Publisher International, India, and United Kingdom, 2021). The Author has also written articles in various international journals in various science fields, such as chemistry, biology, and Pharmacy. 